CZU 657.471.12:331.214.72

https://doi.org/10.52507/2345-1106.2021-1.18

\title{
MANAGEMENT ACCOUNTING OF COSTS FOR HUMAN CAPITAL OF THE SERVICE ENTERPRISE
}

\author{
SOROKA Larysa, \\ $\mathrm{PhD}$ in Economics, Associate Professor, \\ Department of Management \\ of Entrepreneurial and Tourist Activities, \\ Ismail State University of Humanities \\ (Ukraine) \\ UMANETS Tatiana, \\ Lecturer, \\ Department of Management \\ of Entrepreneurial and Tourist Activities, \\ Ismail State University of Humanities
}

(Ukraine)

\begin{abstract}
SUMMARY
The systematic study, critical assessment of theoretical provisions and current practice of accounting organization of costs for human capital of the service enterprise, improvement of accounting mechanisms for the use of personal human assets and human capital of the enterprise are provided in the article. It is proved that the need to reflect human capital in accounting is due to the following factors: human capital is considered an integral part of national wealth; determining the main role of human knowledge, abilities, qualifications, and education in the process of social production; change of attitude to a person that is the appreciation of its creative potential and intellectual abilities. Characteristic definitions of human capital in aspects of different spheres of its functioning are analyzed. Peculiarities of normative and legal regulation of human capital as an intangible asset under SSAP and IFRS and identification of contradictions in accounting of personnel costs under the current accounting system are considered. The peculiarities of the organization of primary accounting of human capital at the enterprises of the service sphere are considered. It has been proposed to record information on the costs for human capital in terms of the processes of its formation, use, and development in the Employee Data Card (standard form P-2) by introducing an additional Section VI "Costs per employee." The financial statements of analytics have been improved to Form No.1 of the Balance Sheet (Statement of Financial Condition) by introducing analytics in the first section of liabilities in the item "Additional capital" of information on human capital of the enterprise, which will generate financial statements for full disclosure to stakeholders, especially investors. Suggestions are given for the prospects of further development: research of accounting of costs for personnel of the enterprise depending on the life cycles of personnel and the enterprise, development of theoretical and methodological bases of corporate social reports on human capital, improvement of personnel value assessment methods (especially residual and liquidation value).
\end{abstract}

Key words: human capital, accounting organization, additional capital, intangible asset, personal human asset.

\section{УПРАВЛЕНЧЕСКИЙ УЧЕТ ЗАТРАТ НА ЧЕЛОВЕЧЕСКИЙ КАПИТАЛ ПРЕДПРИЯТИЯ СФЕРЫ} УСЛУГ

СОРОКА Лариса Николаевна, кандидат экономических наук, доцент, кафедра управления туристической и предпринимательской деятельностью Измаильский государственный гуманитарный университет (Украина)

УМАНЕЦ Татьяна Николаевна, 
преподаватель, кафедра управления туристической и предпринимательской деятельностью Измаильский государственный гуманитарный университет (Украина)

\begin{abstract}
АННОТАЦИЯ
В статье осуществлено системное исследование, критическая оценка теоретических положений и действующей практики организации учета затрат на человеческий капитал предприятия сферы услуг, совершенствование механизмов учета использования персональных человеческих активов и человеческого капитала. Доказано, что необходимость отражения человеческого капитала в бухгалтерском учете обусловленные следующими факторами: человеческий капитал рассматривается как неотъемлемая часть национального богатства; определение главной роли знаний человека, его способностей, квалификации и образования в процессе общественного производства; изменение отношения к человеку - оценка его творческого потенциала и интеллектуальных способностей.

Проанализированы характерные определения человеческого капитала в аспектах различных сфер его функционирования. Рассмотрены особенности нормативно-правового регулирования человеческого капитала как нематериального актива по П(С)БУ и МСФО и выявлении противоречия в учете расходов на персонал при действующей системе учета.

Рассмотрены особенности организации первичного учета человеческого капитала на предприятиях сферы услуг. Было предложено фиксировать информацию о расходах на человеческий капитал в разрезе процессов его формирования, использования и развития в Личной карточке работника (типовая форма П-2) путем введения дополнительного раздела VI "Расходы на работника». Усовершенствовано финансовую отчетность Форму №1 Баланс (Отчет о финансовом состоянии) путем введения аналитики в первом разделе пассивов в статье «Дополнительный капитал» информации относительно человеческого капитала предприятия, что позволит сформировать финансовую отчетность для полного раскрытия информации стейкхолдерам, особенно инвесторам.

Даны предложения по перспективам дальнейших разработок: исследование учета затрат на персонал предприятия в зависимости от жизненных циклов персонала и предприятия, разработка теоретико-методических основ корпоративных социальных отчетов относительно человеческого капитала, совершенствование методики оценки стоимости персоналии (особенно остаточной и ликвидационной стоимости) и др.
\end{abstract}

Ключевые слова: человеческий капитал, организация учета, дополнительный капитал, нематериальный актив, персональный человеческий актив.

Problem statement. A person in a consumer society strives to consume in such a way that, on the one hand, he (she) is no worse than others, and, on the other, he (she) does not merge with the crowd. Individual consumption reflects not only the social characteristics of the consumer (as a demonstration of social status) but also the characteristics of the individual lifestyle. All these features change the personnel of enterprises, while the characteristics (properties) of the personnel themselves change, and specific ones appear depending on the economic activity.

All this requires a change in the worldview of the company to personnel as a special and priority resource - the transformation of the entire resource management system of the enterprise, its components (accounting, analysis, planning, organization, control, etc.). Manifestation of the concept of human capital in the theory of economic thought necessitates the creation of effective information support, which became a prerequisite for the creation of the concept of accounting for human resources (human capital, personnel).

Analysis of recent research and publications. Modern "theory of human capital" as a field of economics, in which the human component of economic systems of different scales is considered in terms of value and price and differs in definition by three levels:

- at the level of personality (nanolevel) human capital is a system of knowledge and abilities that a person has acquired through education, training, practical experience (using their natural abilities) and through which it can provide valuable production services to other people - personal (private) human capital [1-3];

- at the enterprise level (microeconomic level) human capital is the total qualification and professional abilities of all employees of the enterprise, as well as the achievements of the enterprise in the effective organization of labor and personnel development - the intellectual capital of the enterprise [4];

- at the state (macroeconomic level) human capital is the accumulated investment in areas such as education, vocational training and retraining, career guidance and employment, health improvement, etc. National human capital is an essential part of the national wealth of the country [5-6].

In our opinion, to identify the types of human capital and to form appropriate definitions, it would be more appropriate to use an approach that would take into account the differences of individual forms of capital, as this term is the basic "creator" of the concept of "human capital".

The analysis of scientific publications allowed to group different definitions of human capital in aspects of economic, cultural, and social sphere of its functioning and to define characteristic features of the received groups. According to the analysis, it can be concluded that the category of human capital is a multifaceted concept. However, in the economic sense, it is primarily a real source of funds that can be directly invested in the 
development of a particular person or group (team, group, nation, etc.).

Paying tribute to the scientific achievements and practical significance of the results, it should be noted that a number of tasks to compare income and expenditure in human resources, determine the effect of the implementation of specific personnel costs of investment nature, take into account opportunity costs in determining expected future economic benefits, and to elaborate internal (corporate) social reporting are not sufficiently developed.

The purpose of the article. The purpose of the paper is a systematic study, critical assessment of theoretical principles and current practices of accounting organization of costs for human capital of the service enterprise, improvement of accounting mechanisms in terms of the use of personal human assets and human capital of the enterprise.

The task of the article. In accordance with the purpose of the paper, the following tasks are set:

- to investigate the economic content of human capital of the enterprise as an object of accounting;

- $\quad$ to get acquainted with the regulatory and legal support of accounting for human capital of enterprises in Ukraine;

- $\quad$ to study the peculiarities of the organization of primary accounting of human capital;

- to consider the features of synthetic and analytical accounting of human capital;

- $\quad$ to suggest ways to improve the accounting of human capital and personal human assets in the service enterprise.

Presentation of the main material. The inability of the accounting system to aggregate the objects of human capital, and financial reporting under modern standardization to provide market institutions with a formalized assessment and, along with it, the cost characteristics of the company, leads to the use of weakly formalized information models.

We believe that in terms of accounting, human capital is a component of the intangible assets of the enterprise.

Traditional accounting considers only the resources that are the property of the enterprise. Due to the fact that personnel, as a special type of resource, can be neither property nor an object of property, the representatives of traditional accounting do not consider it as an object of accounting - an asset (resources controlled by the enterprise as a result of past events, the use of which, as expected, leads to economic benefits in the future).

In our opinion, the need to reflect human capital in accounting is due to the following factors: human capital is considered an integral part of national wealth; determining the main role of human knowledge, abilities, qualifications, and education in the process of social production; change of attitude to a person - appreciation of its creative potential and intellectual abilities; the transition to a "post-industrial economy" has led to an increase in the role of the non-monetary component of capital, which creates the main part of value added; a significant increase in the share of goodwill in the asset structure of multinational corporations, the precondition for which is the lack of reflection in the accounting of human capital.

We believe that to reflect the costs of personnel development as current costs from an economic point of view is impractical because the cost of professional development, personnel training is not in itself a "used resource", so to include these costs in current costs or cost of production of services for the reporting period is not possible. In addition, including the personnel costs that meet the conditions of capitalization in the period costs, the enterprise thus underestimates its financial result and the value of the assets of the balance sheet.

The valuation model, which is based on the capitalization of labor costs, training and development, will allow to most accurately determine the economic value of labor.

However, there are some inconsistencies in accounting for personnel costs.

First, in accordance with International Financial Reporting Standards (hereinafter - IFRS), the costs incurred by the enterprise can be reflected either as an asset or as period costs, i.e. the concept of "future periods costs" in IFRS is absent [7]. Therefore, when preparing financial statements in accordance with IFRS, if the option of accounting for personnel development costs as future period's costs is chosen, they should be reclassified and identified separately.

Second, it is unacceptable to account for personnel development costs as current costs, as the costs of professional development, preventive examinations, and health improvement of employees are not "used resources", so they cannot be included in current costs or costs of production of goods (works, services) of the period in which they were incurred. In addition, if the personnel costs incurred need to be capitalized, then this accounting option leads to an understatement of the financial result and the value of the assets of the balance sheet.

Thus, we can conclude that the current Ukrainian practice of cost accounting personnel development does not take into account their accounting and economic nature, which ultimately leads to a violation of one of the main principles of accounting - prudence and does not comply with IFRS, and therefore there is the need for improvement. This is especially true of the cost, which accumulates the human capital of the enterprise and increases its value and value for the enterprise.

The formation of human capital in the service sector should take place in two directions:

1. Professional development of personnel: employee training; retraining of employees; advanced training of employees.

2. Personnel retention: personnel health improvement; social services.

It is according to this classification that human capital will be capitalized.

The formation of human capital is due to the receipt of services for training, retraining, etc. It is necessary to form a primary observation of the relationship between the customer and the supplier.

Forms of internal primary accounting documentation are the basis for displaying information on the facts of business transactions in the accounting registers. 
It should be noted that for the accounting of intangible assets, which are proposed to reflect investments in human capital formation, the Ministry of Finance has developed and approved unified forms [8]: Act of introduction of intellectual property into circulation as part of intangible assets (standard form IA-1); Inventory card of registration of the intellectual property as a part of intangible assets (standard form IA-2); Act of disposal (liquidation) of the intellectual property as part of intangible assets (standard form IA-3); Inventory description of intellectual property as part of intangible assets (standard form IA-4).

However, the forms of primary accounting documents can be used to record the relevant employment contracts or training of employees.

At the same time, information on the cost of human capital in terms of the processes of its formation, use, and development can be recorded in the Employee Data Card (standard form P-2) as an additional Section VI "Costs per employee" (Table 1).

Table 1. Employee Data Card - VI "Costs per employee"

\begin{tabular}{|l|l|l|l|}
\hline \multicolumn{1}{|c|}{ Type of costs } & $\begin{array}{c}\text { Amount of } \\
\text { expenses, UAH }\end{array}$ & $\begin{array}{c}\text { Grounds, No } \\
\text { of order }\end{array}$ & Notes \\
\hline 1. Costs for professional development of the employee & & & \\
\hline- Training of employees & & & \\
\hline- Retraining of employees & & & \\
\hline- Advanced training of employees & & & \\
\hline 2. Cost for personnel retention & & & \\
\hline- Health improvement & & & \\
\hline- Social services & & \\
\hline
\end{tabular}

The part of human capital costs (investments in formation and development) that meet the criteria for recognition as intangible assets should be reflected in assets and liabilities, income, and costs.

This type of information must be documented by the relevant package of documents: Contract for the provision of services (performance of works), Order on the search for personnel, Work Completion Certificate, a copy of the announcement, etc.

This approach to the organization of primary accounting of human capital costs will form an effective personnel policy at the enterprise, which will further increase employee loyalty, become a motivating factor, increase productivity, and reduce staff turnover.

Given all the above in the previous sections, we consider it appropriate to introduce separate sub-accounts to account for operations related to the personnel development and retention. With these accounts, the analysis of human capital costs is deepened and the list of accounting objects is expanded, which helps to avoid inconsistencies in the formation of financial results. To account for human capital, a separate synthetic account 128 "Personal human assets" should be created. This account will not take into account the employees themselves but only the rights to use the knowledge and qualifications of employees.

Improvements in accounting methods for the segment of personnel costs in terms of the element "accounts and double entry" are given in Table 2.

Table 2. Synthetic and analytical accounts for management accounting of personnel costs

\begin{tabular}{|c|c|c|c|c|c|c|c|c|}
\hline \multicolumn{9}{|c|}{128 "Personal human assets" } \\
\hline \multicolumn{2}{|c|}{$\begin{array}{l}128.1 \text { "Personal } \\
\text { (human) assets of } \\
\text { accounting service" }\end{array}$} & \multicolumn{2}{|c|}{$\begin{array}{c}128.2 \text { "Personal (human) } \\
\text { assets of personnel } \\
\text { service" }\end{array}$} & \multicolumn{2}{|c|}{$\begin{array}{c}128.3 \text { "Personal } \\
\text { (human) assets of the } \\
\text { legal department" }\end{array}$} & \multicolumn{2}{|c|}{$\begin{array}{c}128.4 \text { "Personal } \\
\text { (human) assets of the } \\
\text { administration" }\end{array}$} & \multirow{2}{*}{$\begin{array}{c}\text { 128.N "Personal } \\
\text { (human) assets of the n- } \\
\text { th division" }\end{array}$} \\
\hline \multicolumn{8}{|c|}{99 "Human resources development costs" } & \\
\hline \multicolumn{5}{|c|}{991 "Professional development costs" } & \multicolumn{3}{|c|}{992 "Personnel retention costs" } & \multirow[b]{2}{*}{$\begin{array}{l}993 \text { "Costs for pseudo- } \\
\text { human development" }\end{array}$} \\
\hline $\begin{array}{c}991.1 \text { "Training } \\
\text { costs" }\end{array}$ & $\begin{array}{r}991 . \\
\text { retr }\end{array}$ & $\begin{array}{l}2 \text { "Employees } \\
\text { aining costs" }\end{array}$ & \multicolumn{2}{|c|}{$\begin{array}{l}991.3 \text { "Advance } \\
\text { training costs" }\end{array}$} & \multicolumn{2}{|c|}{$\begin{array}{l}\text { 992.1 Costs for } \\
\text { health } \\
\text { improvement of } \\
\text { personnel }\end{array}$} & $\begin{array}{l}992.2 \text { Costs for } \\
\text { social services }\end{array}$ & \\
\hline \multicolumn{9}{|c|}{ 154.1. "Recognized personal (human) assets" } \\
\hline \multicolumn{9}{|c|}{ 154.1.1 "Recognized personal (human) assets of the accounting service" } \\
\hline
\end{tabular}




\begin{tabular}{|c|c|c|c|c|}
\hline 154.1.1.1 "Training" & $\begin{array}{c}\text { 154.1.1.2 "Retraining of } \\
\text { employees" }\end{array}$ & $\begin{array}{c}154.1 .1 .3 \text { "Advanced } \\
\text { training of employees" }\end{array}$ & $\begin{array}{c}154.1 .1 .4 \text { "Health } \\
\text { improvement" }\end{array}$ & $\begin{array}{c}154.1 .1 .5 \text { "Social } \\
\text { services" }\end{array}$ \\
\hline \multicolumn{3}{|c|}{426 "Human capital of the enterprise" } \\
$\begin{array}{c}426.1 \text { "Human capital } \\
\text { of the accounting" }\end{array}$ & $\begin{array}{c}426.2 \text { "Human capital } \\
\text { of personnel service" }\end{array}$ & $\begin{array}{c}426.3 \text { "Human capital } \\
\text { of the legal } \\
\text { department" }\end{array}$ & $\begin{array}{c}426.4 \text { "Human capital } \\
\text { of the administration" }\end{array}$ & $\begin{array}{c}426 . \mathrm{N} \text { "Human capital } \\
\text { of the n-th division" }\end{array}$ \\
\hline
\end{tabular}

Service enterprises in many cases conduct multidirectional activities and, for the convenience of management accounting, costs and revenues are determined by the centers of responsibility. For example, if the service enterprise is a hotel complex, then it is convenient to account for costs and revenues separately for the actual hotel, restaurant, and other subsystems of the complex. This requires the need to introduce analytical accounting of employees' human capital development costs by centers of responsibility and by cost items.

Thus, in accordance with the current methodology, in the form No.1 "Balance Sheet (Statement of financial condition)", the assets provide information on noncurrent assets, current assets and non-current assets held for sale, and disposal group, liabilities provide information on equity, long-term, and current liabilities. In accordance with the terms of the double entry of business transactions, our proposals for improving Form No.1 relate to:

- in the first section of assets "Non-current assets", the value of objects that are classified as intangible assets is displayed, in which we propose to reflect personal human assets;

- in the first section of liabilities in the item "Additional capital", we propose to reflect the formed human capital of the enterprise. That is why we consider it expedient to introduce additional articles to this section (Table 3).

Table 3. Fragment of the form No.1 "Balance Sheet (Statement of Financial Condition)" (author's suggestions)

\begin{tabular}{|c|c|c|c|}
\hline Liabilities & $\begin{array}{l}\text { Line } \\
\text { code }\end{array}$ & $\begin{array}{l}\text { At the beginning of } \\
\text { the reporting period }\end{array}$ & $\begin{array}{l}\text { At the end of the } \\
\text { reporting period }\end{array}$ \\
\hline Additional capital & 1410 & 130 & 260 \\
\hline & & & \\
\hline including human capital* & 1631 & 26 & 75 \\
\hline
\end{tabular}

In our opinion, the proposed structure of accounts and the working plan of accounting accounts at the enterprise will: increase the in formativeness of accounting data for effective management decisions; clearly separate and analyze the cost of human capital components of an individual employee and the cost of human capital of the enterprise as a whole by summarizing the information on analytical accounts; reflect human capital in the assets; allow to approximate the book value of the enterprise with its market value.

Conclusions and prospects for further research. In general, human capital at the personal level at the microeconomic and macroeconomic levels is considered. The characteristic definitions of human capital in aspects of different spheres of its functioning were also analyzed. In our opinion, the need to reflect human capital in accounting is due to the following factors: human capital is considered an integral part of national wealth; determining the main role of human knowledge, abilities, qualifications, and education in the process of social production; change of attitude to a person - appreciation of its creative potential and intellectual abilities; the transition to a "post-industrial economy" has led to an increase in the role of the non-monetary component of capital, which creates the main part of value added; a significant increase in the share of goodwill in the asset structure of transnational corporations, the precondition for which is the lack of reflection in the accounting of human capital.

The peculiarities of the organization of primary accounting of human capital at the service enterprises are considered. It was proposed to record information on the cost for human capital in terms of the processes of its formation, use, and development in the Employee Data Card (standard form P-2) by introducing an additional Section VI "Costs per employee".

Prospects for further development are the study of accounting for personnel costs of the enterprise depending on the life cycles of personnel and the enterprise, development of theoretical and methodological principles of corporate social reports on human capital, improvement of personnel valuation techniques (especially residual and liquidation value). 


\section{Bibliographic references:}

1. Cleary P., Quinn, M. Intellectual capital and business performance: An exploratory study of the impact of cloudbased accounting and finance infrastructure. Journal of Intellectual Capital. 2016. 17(2). P. 255-278.

2. Cuozzo B., Dumay J., Palmaccio M., Lombardi R. Intellectual capital disclosure: a structured literature review. Journal of Intellectual Capital. 2017. 18(1). P. 9-28.

3. Dumay J. A critical reflection on the future of intellectual capital: from reporting to disclosure. Journal of Intellectual capital. 2016. 17(1). P. 168-184.

4. Goldin C. Human capital. Handbook of cliometrics. 2016. P. 55-86.

5. Guthrie J., Parker L. D. Whither the accounting profession, accountants and accounting researchers? Commentary and projections. Accounting, Auditing \& Accountability Journal. 2016. 29(1). P. 2-10.

6. Secundo G., Dumay J., Schiuma G., Passiante G. (2016). Managing intellectual capital through a collective intelligence approach: An integrated ramework for universities. Journal of Intellectual Capital. 2016. 17(2). P. $298-319$.

7. Міжнародний стандарт бухгалтерського обліку 38 «Нематеріальні активи». URL: http://zakon4.rada.gov.ua/laws/show/929_050/page (дата звернення: 09.01.2021).

8. Про затвердження типових форм первинного обліку об'єктів права інтелектуальної власності у складі нематеріальних активів. URL: http://zakon2.rada.gov.ua/ laws/show/z1580-04 (дата звернення: 09.01.2021). 